\title{
Retained placenta in Friesian mares: incidence, risk factors, therapy, and consequences
}

\author{
M. Sevinga ${ }^{1}$, H.W. Barkema ${ }^{2}$ and J.W. Hesselink ${ }^{3}$ \\ 'Veterinary Practice Mid-Fryslân, Akkrum, The Netherlands; ${ }^{2}$ Animal Health Service, Drachten, The Netherlands \\ ${ }^{3}$ University Hospital Groningen, Groningen, The Netherlands
}

\begin{abstract}
Summary
This study concerns incidence, risk factors, therapy and consequences of retained placenta after normal foalings in Friesian mares. Retained placenta was defined as failure to expel all fetal membranes within 3 hours after the delivery of the foal. Incidence of retained placenta was studied in 495 parturitions. As possible risk factors for retained placenta, serum calcium, magnesium ( $n=155)$, and vitamin-E concentrations, and glutathion peroxidase activity in blood $(n=99)$ were determined within 12 hours post partum and compared between mares with and without retained placenta. Age of the mare, sex of the foal, gestational length and recurrence of retained placenta were recorded and also compared between mares with and without retained placenta. As therapy, the relative effectiveness of intra venous administration of oxytocin in saline solution $(n=59)$ and of oxytocin in a Ca-Mg-borogluconate solution $(n=53)$ was studied. Parameters for post partum reproductive performance were compared between mares with $(n=54)$ and without retained placenta $(n=50)$, and within the group of mares with retained placenta, of mares from which the fetal membranes had been removed manually $(n=30)$ and from which it was not $(n=24)$.

Incidence of retained placenta in Friesian mares was $54 \%$. Mares which retained the placenta had lower serum calcium concentrations within 12 hours post partum than mares without retained placenta $(P<0.05)$, whereas mean serum magnesium and vitamin-E concentrations, and glutathion peroxidase activity in blood showed no difference. Age of the mare, sex of the foal and gestational length were not different between mares with and without retained placenta. Mares which had retained the placenta after previous foalings, had a 2.9-fold increase of retained placenta. Sixty four percent of the mares treated with oxytocin in Ca-Mg-borogluconate solution responded positively to the treatment, compared to $44 \%$ of the mares treated with oxytocin in saline solution $(P<0.05)$. Post partum reproductive performance did not differ between mares with and without retained placenta, and of the mares with retained placenta, between mares with and without manual removal of the placenta.
\end{abstract}

Keywords: $\quad$ Friesian mares, retained placenta, incidence, risk factors, therapy

\section{Retentio secundinarum bei Friesenstuten: Vorkommen, Risikofaktoren, Therapie und Folgen}

Die Studie behandelt die Inzidenz, Therapie und Folgen einer Retentio secundinarum nach normaler Abfohlung bei Friesenstuten. Die Retentio secundinarum wurde als mangelnder Abgang aller fetalen Membranen innerhalb von 3 Stunden nach der Geburt des Fohlens definiert. Zur Ermittlung des Vorkommens der Nachgeburtsverhaltung wurden 495 Geburten untersucht. Um mögliche Risikofaktoren zu bestimmen, wurden die Serumwerte von Kalzium, Magnesium $(n=155)$ und Vitamin E sowie die Glutathionperoxidase-Aktivität im Blut innerhalb von 12 Stunden post partum bestimmt und die Werte zwischen den Stuten mit und ohne Retentio secundinarum verglichen. Das Alter der Stuten, das Geschlecht des Fohlens, die Trächtigkeitsdaver und das Wiederauftreten einer Nachgeburtsverhaltung wurde protokolliert und ebenfalls zwischen den Gruppen verglichen. Als Therapie wurde die relative Effektivität intravenöser Gaben von Oxyłocin in Kochsalzlösung ( $\mathrm{n}=59$ ) und Oxyłocin in einer Ca-MgBorogluconatlösung $(n=53)$ untersucht. Die postpartalen Fertilitätsparameter wurden zwischen den Stuten mit $(n=54)$ und ohne $(n=50)$ verzögerten Plazentaabgang und zwischen den Stuten mit $(n=30)$ und ohne $(n=24)$ manueller Abnahme der Plazenta verglichen.

Die Inzidenz einer Retentio secundinarum betrug bei den Friesenstuten 54\%. Stuten mit einer Nachgeburtsverhaltung hatten 12 Stunden post partum eine niedrigere Serumkalziumkonzentration als Stuten ohne Störung des Plazentaabgangs $(\mathrm{P}<0.05)$. Hingegen wurden keine Unterschiede bezüglich der mittleren Serummagnesium- und Vitamin-E Konzentration sowie der Glutathionperoxidase-Aktivität im Blut festgestellt. Auch bezogen auf das Alter der Stuten, das Geschlecht des Fohlens und die Trächtigkeitsdaver konnten keine Unterschiede zwischen den Gruppen nachgewiesen werden. Stuten, die bei vorherigen Abfohlungen bereits einen verzögerten Plazentaabgang gezeigt hatten, besaßen eine 2,9-fach erhöhte Rate einer erneuten Retentio secundinarum. 64\% der Stuten, die mit Oxytocin in einer Ca-Mg-Borogluconatlösung behandelt wurden, reagierten positiv auf die Behandlung, verglichen mit 44\% der mit Oxytocin in Kochsalzlösung behandelten Stuten $(P<0.05)$. Die postpartale Fertilität zwischen Stuten mit und ohne Retentio secundinarum und zwischen Stuten mit und ohne manueller Plazentaabnahme unterscheidet sich nicht.

Schlüsselwörter: Friesenstuten, Retentio secundinarum, Inzidenz, Risikofaktoren, Therapie

\section{Introduction}

\section{Definition and incidence}

Retained placenta (RP) in the mare is defined as a failure to expel all or a part of the fetal membranes within a specific period of time after delivery of the foal (Threlfall, 1992). This period of time is usually considered to be 3 hours. Normally, the fetal membranes are expelled within 30 minutes to 3 hours after parturition (Blanchard and Varner, 1993). The reported incidence of RP in mares varies from 2 to $10 \%$ of foalings (Vandeplassche, 1971), although the incidence of RP in Friesian mares in The Netherlands is estimated to be approximately $35 \%$.

\section{Risk factors}

In the cow, hypocalcemia, which is often accompanied by hypomagnesemia (van de Braak et al., 1987) is a risk factor for 
RP (Chassagne and Chacornac, 1994). Furthermore, the level of hypocalcemia on the first day postpartum in cows is positively associated with age (Bigras-Poulin and Tremblay, 1998). In the mare, however, no differences have been found in serum calcium levels between animals of different age and reproductive stages (Zepperitz and Gurtler, 1992). In mares without RP, serum calcium levels have been found to decrease from 3 days before to 2 days after parturition (Martin et al., 1996).

In cattle, the incidence of RP was reduced by selenium and vitamin-E supplementation (Brzezinska-Slebodinska et al., 1994). In horses, reproductive difficulties such as RP have been attributed to selenium and/or vitamin-E deficiency and differences in selenium metabolism in horses might be breed related (Hayes et al., 1987).

The objective was to study possible risk factors for RP. Therefore serum calcium, magnesium and vitamin-E concentrations and glutathion peroxidase activity in blood were compared between mares with and without RP. Age of the mare, sex of the foal, gestational length and recurrence of RP were also studied.

\section{Therapy}

Actually, the systemic use of oxytocin is considered as the most appropriate therapy in cases of RP (Perkins, 1999). In vitro studies showed that oxytocin and calcium interact in the regulation of uterine contractility (Coruzzi et al., 1989; Holda et al., 1996). The objective was to determine the relative effectiveness of intravenous administration of oxytocin dissolved in saline as compared to oxytocin dissolved in a Ca-Mg-borogluconate solution as a treatment of equine RP.

\section{Consequences}

In various breeds of horses, especially in case of RP, decreased pregnancy rates after insemination in the foal heat and an increased interval between delivery and conception were found, which were associated with a disturbed involution of the genital system (Glatzel and Belz, 1995; Belz and Glatzel, 1995). However, in a study on Standardbred mares, RP was not found to affect reproductive performance, and in mares with RP, the pregnancy rate was similar after breeding in the foal heat versus breeding in other heats (Provencher et al., 1988). When the

Tab. 1: Frequencies of studied parameters per group of mares with and without retained placenta (RP) in the study

Häufigkeit der untersuchten Parameter pro Gruppe von Stuten mit und ohne Retentio secundinarum (RP)

\begin{tabular}{|l|c|c|c|}
\hline \multicolumn{4}{|c|}{ Group of mares } \\
\hline Parameter & with RP (SD) & without RP & P-value \\
\hline Age (yrs.) & $8.7(4.0)$ & $8.9(4.1)$ & 0.78 \\
\hline Gestational length (days) & $332(6.1)$ & $331 \quad(6.8)$ & 0.44 \\
\hline Fillies (\%) & 55 & 56 & 0.93 \\
\hline Recurrence (\%) & 60 & 34 & 0.0089 \\
\hline
\end{tabular}

initial oxytocin treatment is ineffective, subsequent manual removal of the placenta is a frequently performed treatment in the Netherlands.

Post partum reproductive performance of Friesian mares with and without RP was studied and, of the mares with RP, also in mares with and without manual removal of the placenta.

\section{Materials and methods}

Study population and data collection

In this field study, exclusively Friesian brood mares were included. Retained placenta was defined as failure to expel all or a part of the fetal membranes within 3 hours following delivery of the foal. In case of dystocia, mares were excluded from the study. Of 495 parturitions, incidence of RP was determined, and age of the mare, sex of the foal, and gestational length were recorded and compared between mares with and without RP.

Blood samples were obtained from the jugular vein within 12 hours post partum. Serum calcium and magnesium concentrations $(n=155)$ were determined using Atomic Absorption Spectrophotometry. Vitamin-E concentrations were determined using High Performance Liquid Chromatography $(n=99)$ and glutathion peroxidase activity $(n=99)$ using the method described by Atroshi et al. (1987).

In order of appearance, mares with RP were treated intravenously (jugular vein) with either $50 \mathrm{IU}$ oxytocin dissolved in $500 \mathrm{~mL}$ saline solution $(n=59)$ containing $0.154 \mathrm{~mol} / \mathrm{L}$ sodium and $0.154 \mathrm{~mol} / \mathrm{L}$ chloride, or $50 \mathrm{IU}$ oxytocin dissolved in $450 \mathrm{~mL}$ Ca-Mg-borogluconate solution ( $n=53$ ) containing $0.180 \mathrm{~mol} /$ $\mathrm{L}$ calcium and $0.082 \mathrm{~mol} / \mathrm{L}$ magnesium. All infusions lasted about 15 minutes. A positive response to treatment was defined as the expulsion of the entire placenta within 2 hours of the infusion without additional treatment.

Mares with RP were treated with oxytocin or oxytocin combined with Ca-Mg-borogluconate solution. When the fetal membranes were not expelled within 2 hours of treatment, the placenta was removed manually. Subsequently, the uterine cavity was then flushed with large amounts of water (50-100 litres). The following parameters were used to compare reproductive performance between mares with $(n=54)$ and without $\operatorname{RP}(n=50)$ and mares with $(n=30)$ and without $(n=24)$ manual removal of the placenta: 1$)$ interval between delivery and conception, 2) efficacy rate, 3) seasonal pregnancy rate, 4) pregnancy rate after first insemination in the foal heat (first estrus within 19 days postpartum), or in a subsequent heat, 5) pregnancy loss rate, and 6) foaling rate.

\section{Statistical analysis}

Student's t-test was used to compare the age of the mares, gestational length, serum calcium and magnesium concentrations, vitamin-E concentrations, glutathion peroxidase activity, interval between delivery and conception, and efficacy rate. Sex of the foal, pregnancy rates, foaling rate, pregnancy loss rate, and differences between the results of the two treatments for RP were tested using Pearson's chi-square analysis on contingency tables.

Statistical significance was declared at $\mathrm{P}<0.05$. 


\section{Results}

The incidence of RP was $54 \%$.

Per group of mares with and without RP, results of age, gestational length, sex of the foal and recurrence of RP are shown in Table 1 .

Age of the mare, gestational length and sex of the foal didn't differ between mares with and without RP. Mares that had RP before, had a 2.9-fold increase compared with mares that had RP for the first time.

Results of biochemical analyses are shown in Table 2 .

Tab. 2: Parameters per group of Friesian mares with (RP) and without retained placenta (no RP).

Parameter pro Gruppe von Friesenstuten mit Retentio secundinarum $(R P)$ und ohne verzögertem Plazentaabgang (no RP)

\begin{tabular}{|c|c|c|c|}
\hline \multicolumn{4}{|c|}{ Mare status } \\
\hline Parameter & $\mathrm{RP} \mathrm{a}^{\mathrm{a}}$ & no RP & P-value \\
\hline $\begin{array}{l}\text { Serum calcium } \\
\text { concentration }(\mathrm{mmol} / \mathrm{L})\end{array}$ & $3.08 \quad(90)$ & $3.18 \quad(65)$ & 0.0004 \\
\hline $\begin{array}{l}\text { Serum magnesium } \\
\text { concentration }(\mathrm{mmol} / \mathrm{L})\end{array}$ & $0.84 \quad(90)$ & $0.85 \quad(65)$ & 0.38 \\
\hline $\begin{array}{l}\text { Serum vitamin-E } \\
\text { concentration }(\mu \mathrm{g} / \mathrm{mL})\end{array}$ & $2.54 \quad(54)$ & $2.49 \quad(45)$ & 0.81 \\
\hline $\begin{array}{l}\text { Glutathion peroxidase } \\
\text { activity }(\mathrm{U} / \mathrm{gHb})\end{array}$ & $172.24(54)$ & $173.07(45)$ & 0.96 \\
\hline
\end{tabular}

aNumbers in parentheses are the number of observations

As shown in Table 2, mares with RP had lower serum calcium concentrations within 12 hours post partum than mares without $R P$, whereas serum magnesium concentrations, vitamin-E concentrations and glutathion peroxidase activity were not different. There were more positive responses to treatment among mares treated with oxytocin in Ca-Mg-borogluconate solution, than among mares treated with oxytocin in saline (Table 3; Chisquare $=4.53,1 \mathrm{df}, \mathrm{P}=0.03)$.

Tab. 3: Results of treatments with oxytocin in saline or oxytocin in Ca$\mathrm{Mg}$-borogluconate solution of Friesian mares with retained placenta.

Ergebnisse der Therapie mit Oxyłocin in Kochsalzlösung oder Oxyłocin in Ca-Mg-borogluconat-Lösung bei Friesenstuten mit Retentio secundinarum

\begin{tabular}{|l|c|c|c|c|}
\hline \multicolumn{4}{|c|}{ Response to treatment } \\
\hline & \multicolumn{2}{|c|}{ Positive $^{\mathrm{a}}$} & \multicolumn{2}{c|}{ Negative } \\
Treatment & $\mathrm{n}$ & $\%$ & $\mathrm{n}$ & $\%$ \\
\hline Oxytocin in saline & 26 & $44^{\mathrm{b}}$ & 33 & 56 \\
\hline $\begin{array}{l}\text { Oxytocin in Ca-Mg- } \\
\text { borogluconate }\end{array}$ & 34 & $64 \mathrm{c}$ & 19 & 36 \\
\hline
\end{tabular}

axpulsion of the placenta within 2 hours of treatment

b,cNumbers within a column with different superscripts are different $(P<0.05)$
Post partum reproductive performance did not differ between mares with and without RP and, within the group of mares with $\mathrm{RP}$, between mares with and without manual removal of the placenta. Parameters of the mares with and without RP are shown in Table 4.

Tab. 4: Reproductive performance parameters of Friesian mares with $(n=54)$ and without $(n=50)$ retained placenta.

Reproduktionsparameter bei Friesenstuten mit $(n=54)$ und ohne $(n=50)$ Retentio secundinarum

\begin{tabular}{|l|c|c|c|}
\hline \multicolumn{4}{|c|}{ Group of mares } \\
\hline Parameter & $\begin{array}{l}\text { Retained } \\
\text { placenta }\end{array}$ & $\begin{array}{l}\text { No retained } \\
\text { placenta }\end{array}$ & P-value \\
\hline $\begin{array}{l}\text { Interval delivery-conception } \\
\text { (days) }\end{array}$ & 27 & 30 & 0.80 \\
\hline Efficacy rate & 1.5 & 1.6 & 0.32 \\
\hline Seasonal pregnancy rate (\%) & 93 & 86 & 0.25 \\
\hline $\begin{array}{l}\text { Pregnancy rate (\%) after first } \\
\text { insemination in: }\end{array}$ & & & 0.64 \\
\cline { 2 - 5 } & 50 & 44 & 0.87 \\
\cline { 2 - 5 } & 52 & 56 & 0.42 \\
\hline Pregnancy loss rate (\%) & 12 & 11 & 82 \\
\hline Foaling rate (\%) & 88 & & \\
\hline
\end{tabular}

\section{Discussion}

Regarding the reported incidence of equine RP, the incidence of $\mathrm{RP}$ in Friesian mares in our study is high. Retained placenta in draft horses also is a rather common event (personal communication W.R. Allen), and therefore RP could be a breed related disease. The population of Friesian horses has increased from 500 registered horses in the 1960's to 30.000 horses. A small effective population can lead to inbreeding. Further study is initiated to obtain knowledge on the possible relationship between RP and inbreeding in Friesian mares.

The higher incidence of RP in mares that exhibited RP before is in accordance with Provencher (1988) who reported a threefold risk. It was suggested that certain mares had a predisposition to RP, possibly due to different hormone profiles at foaling or pathological changes of the genital tract. Friesian mares with RP in our study had lower serum calcium concentrations than mares without RP. Therefore, uterine activity might be altered in mares with RP. This could be related to the larger number of mares which responded positively to the combined treatment of oxytocin and calcium-magnesium-borogluconate.

With regard to post partum reproductive performance, we did not find any difference between mares with and without RP and between mares with RP, with and without manual removal of the placenta. The results are comparable with the findings for Standardbred mares with RP, reported by Provencher et al. (1988). In contrast, two German studies reported a decreased reproductive performance after RP in different breeds of horses, 
associated with a disturbed involution of the genital system (Glatzel and Belz, 1995; Belz and Glatzel, 1995). The latter could be due to the administration of an intrauterine treatment post partum with an antiseptic solution. After manual removal of the placenta, flushing the uterine cavity with large amounts of water (50-100 litres) was part of the treatment protocol in our study. This might have removed cellular debris, which is an excellent substrate for bacterial growth. The pregnancy rate after insemination in the foal heat compared with the pregnancy rate after insemination in a subsequent heat was not different between mares with and without RP, and with and without manual removal of the placenta. This indicates that the foal heat can be effectively used for breeding, even after RP and manual removal.

In conclusion, the incidence of RP in Friesian mares is high and RP in Friesian mares needs therefore further investigation.

A decreased serum calcium concentration within 12 hours post partum is a risk factor for RP in Friesian mares. Further, the use of a combined oxytocin and calcium-magnesium-borogluconate treatment is more effective than a treatment with oxytocin in saline.

Post partum reproductive performance was not different between Friesian mares with and without RP, and in mares with RP, between mares from which the placenta had been removed manually and from which it was not. Retained placenta and manual removal of the placenta are no reason to advice against foal heat breeding.

\section{Literature}

Atroshi, F., Sankari, S., Ostenberg, S. and Sandholm, M. (1981): Variation of erythrocyte glutathion peroxidase activity in Finn Sheep. Res Vet Sci; 31, 267-271

Belz, J. P. and Glatzel, P. S. (1995): Fertility in mares after a disturbed as well as an undisturbed puerperium: significance of histological and cytological examinations of the uterus. Tierärztl Prax; 23, 267-272

Bigras-Poulin, M. and Tremblay, A. (1998): An epidemiological study of calcium metabolism in non-paretic postpaturient Holstein cows. Prev Vet Med; 35, 195-207

Blanchard, T. L. and Varner, D. D. (1993): Therapy for retained placenta in the mare. Vet Med; 88, 55-59

Braak van de, A. E., van 't Klooster, A. T. and Malestein, A. (1987): Influence of a deficient supply of magnesium during the dry period on the rate of calcium mobilisation by dairy cows at parturition. Res Vet Sci; 42, 101-108
Brzezinska-Slebodinska, E., Miller, J. K., Quigley, J. D. $3^{\text {rd }}$, Moore, J. R. and Madsen, F. C. (1994): Antioxidant status of dairy cows supplemented prepartum with vitamin E and selenium. J Dairy Sci; 77, 3087-95

Chassagne, M. and Chacornac, J. P. (1994): Markers of nutritional risk for placental retention: use of blood analysis at the end of gestation. Vet Res; 25, 191-195

Coruzzi, G., Poli, E. and Bertaccini, G. (1989): Effect of calcium-channel blockers and salbutamol on the isolated mare uterus - interaction with the calcium agonist Bay K 8644. J Vet Pharmacol Ther; 12, 404-410

Glatzel, P. S. and Belz, J. P. (1995): Fertility in mares after disturbed or undisturbed puerperium; evidence from clinical, microbiological and hormone analysis. Berl Münch Tierärzłl Wochensch; 108, 376379

Hayes, J. W., Stiner, C. G., Holmes, M. J. and Mackenzie, S. A. (1987): Comparison of selenium blood levels and dietary selenium in three breeds of horses. Equine Practice; 9, 25-9

Holda, J. R., Oberti, C., Perez-Reyes, E. and Blatter, L. A. (1996): Characterization of an oxytocin-induced rise in $[\mathrm{Ca} 2+]$ i in single human myometrium smooth muscle cells. Cell Calcium; 20, 4351

Martin, K. L., Hoffman, R. M., Kronfeld, D. S., Ley, W. B. and Warnick, L. D. (1996): Calcium decreases and parathyroid hormone increases in serum of periparturient mares. J Anim Sci; 74, 834-839

Perkins, N. R. (1999): Equine reproductive pharmacology. Vet Clin North Am Equine Pract; 15, 687-704

Provencher, R., Threlfall, W. R., Murdick, P. W. and Wearly, W. K. (1988): Retained fetal membranes in the mare: a retrospective study. Can Vet J; 29, 903-910

Threlfall, W. R. (1992): Retained placenta. In: Equine Reproduction $1^{\text {st }}$ ed Ed AO McKinnon, JL Voss, Lea \& Febiger, Philadelphia; 61 4-621

Vandeplassche, M., Spincemaille, J. and Bouters, R. (1971): Aethiology, pathogenesis and treatment of retained placenta in the mare. Equine Vet J; 3, 144-147

Zepperitz, H. and Gurtler, H. (1992): lonized calcium and total calcium in the blood of cattle, sheep, swine and horses of different ages, reproductive stages and uses. Berl Münch Tieräztl Wochenschr; 105, 328-332

Dr. Mello Sevinga

Vet. Pract. Mid-Fryslan

Lange Miente 5

8491 BG Akkrum

The Netherlands

Tel.: 0031-566-652008

Fax.: 0031-566-651205

e-mail: sevinga@xs4all.nl 